\title{
ARCHITECTURAL FORM OF THE EXTERNAL WALL IN CONCRETE BUILDINGS DESIGNED BY TOMOYA MASUDA
}

\author{
長岡大樹 — $* 1$ \\ キーワード : \\ 増田友也, 建築家, 壁面構成, ファサード, 打放しコンクリート, \\ ルーバー
}

Keywords:

Tomoya Masuda, Architect, Spatial composition of wall, Facade,

Exposed concrete, Louver

\section{1. 序}

本稿では、建築家・増田友也の建築作品を考察する。増田友也 (1914-1981) は、1950 年から 1978 年まで京都大学建築学教室で教育・ 研究・設計活動を行った。京大退官を記念して編まれた『著作・作品 目録』には、著作は 61 題·建築作品は 84 作品 (実施案 61、計画案 23) とある ${ }^{1)}$ 。著作は、増田の没後『増田友也著作集』にまとめられた ${ }^{2)}$ 。 しかし建築作品は、作品集や雑誌特集を通してその全貌が紹介され たことはない ${ }^{3)}$ 。筆者は、増田の建築作品に関わる資料の収集を進め、 このたび全作品の外観 (外壁面)の意匠を把握するまでに至った。

増田は京大増田研究室を拠点に旺盛な設計活動を行った。建築作 品のほとんどは鉄筋コンクリート造で、壁面の全体から細部(例えば手摺壁 やその支柱）に至るまで可能な限りコンクリートだけで造られた。こうし た造形方針は生涯変わらず、一貫して鉄筋コンクリートによる空間表現が 追求された。特に壁の形態は、節度を保ちながらも様々で、建築表現 の展開がよくみてとれる。一方著作でも、建築の初発的表現として、 「壁による隔離」という空間現象が何度も引合いに出された ${ }^{4)}$ 。増田 は、建築を発生させる原初的な動機として「外界から隔離されている こと」「囲われていること」を挙げており、「壁を立て、隔てる」という 建築的行為に特別な意味を見出していたと思われる。ここでは増田 が実現させた建築作品の壁を取りあげ、その形態分析を行う。

本稿の目的は、増田の建築作品の特徵と変遷 (年代的傾向) を記述 し、そこに建築表現の型(形式)を見出すことである。ここでは壁の 「形態構成」を問題とするがその意義は二点ある。まず壁の造形を 「構成的要素による構築」として記号的・構造的に捉えることで、建物 用途や敷地条件に左右されることなく、対象作品す心゙てを同じ尺度 で記述できる。また作品間の差異や類似といった関係性から「建築家 固有の表現」を描くことができる。このように本研究は、建築空間の 意味や創作理念までは問題としておらず、専ら壁の造形の形式的な 特徵を取り扱う。形態分析に終始する本稿ではあるが、例えば増田が ある表現に固執していた時期や建築表現を大きく切り替えた時期が わかれば、同時期の著作（建築論）との照会が可能となる。増田は

\section{Daiju NAGAOKA — $* 1$}

The purpose of this study is to clarify the architectural style and work of Tomoya Masuda (1914-1981). He organized his own architectural studio Atelier Masuda in Kyoto university, and there he designed many exposed concrete buildings. The architectural form of external walls on the facade is characterized by several aspects, such as the architectural vocabulary of facade design, the additional element, the overlap of surface elements. As a result, his architectural work is divided four stages by the change of facade motif 1) eaves 2 ) frame with wing walls and flat roof slab 3) roof and massive wall 4) wall covered with louver.

「思索なくして制作はなく、制作なくして思索はない」 ${ }^{7)}$ という立場 にいた。増田の建築と建築論を包括的に考察するためには、増田友也 研究の早い段階で、建築表現の枠組みを把握しておく必要がある。

増田の建築作品を取りあげた既往文献を整理すると、(1)代表的な 一作品の意匠的特徵を増田の思惟と共に解説したもの ${ }^{712)}$ 、(2)設計 活動の紹介として主な作品を列記し、作品総体の特徴を簡潔に述べ たもの ${ }^{6) 89913)}$ 、(3)主要な作品に通底する歼-7や手法を指摘したもの 5) 10)11) がある ${ }^{14)}$ 。これに対して本稿は、全作品の形態構成を初めて 分析したものである。各作品の壁面意匠の記述とその類型化を行い、 増田特有の表現形式の一端を明らかにしようとするものである ${ }^{15)}$ 。

\section{2. 壁の造形分析}

分析を行ったのは、記念碑や給油所といった内と外を隔てる壁の ない建物および目録掲載のない最初期の住宅群を除いた「すべての 実現作」と、計画案で終わった「京大会館」を合わせた 61 の作品で ある (表 1) ${ }^{16)}$ 。No. 12、35、46 の鉄骨造を除いて 58 の作品が鉄筋コンクリ 一トの構造で、61 作品中 50 の建物が「コンクリート打放し」仕上げであった。

意匠や作風の変遷を読み取るために、建物の着工を設計案の確定 と捉えて、全 61 作品を「着工年月順」に並べた(表 1 )。検討したのは、 建物のいわば顔といえるフアサードの壁面（主入口のある壁面、広場や 道路、南の方向に面した壁面のいずれか) である。壁の機能は、「建物 に相応しい外観を与えること」「内と外を隔てること」の二点に集約 される。したがって壁の造形として、「外壁面の構成」と「内と外の 境界を構成する壁面要素の前後関係」の二点を分析した。

\section{2-1. 外壁面の構成}

全作品を通覧すると、壁体に庇や屋根が付帯するかどうかが、壁面 意匠の大きな違いをつくっていた。したがって外壁面をまず性格づ けるのは、「庇・屋根・壁」の有無と組合せといえる。そして壁面上 での「庇・屋根・壁」各要素の造形的特徵を検討したところ、全作品 から 8 種類の「壁面の構成手法」が抽出できた（図 1)。庇による壁面 の構成手法は、(1)庇が壁体からキャ゙ティレ゙ーで張出し、フアサードに水平の 
帯を与える「張出し庇」。(2)庇の役割を果たす屋根人ラブと両少价゙の袖 壁が、壁面全体を門型 ( П形)に枠づける「壁面全体の門型枠」である。 屋根による壁面の構成手法は、(3)屋根を壁から持上げて、壁の輪郭 (特に壁の上辺)を際立たせる「屋根の持上げ」がみられた。壁によ る構成手法は、(4)建物の骨組である柱・梁の方形架構を壁面全体に 表出させる「柱梁による方形架構」。(5)一枚の重厚な壁を建物の正面 に据え内外を隔てる「重厚な一枚壁」。この壁面には石張りやコンクリート 目地切り等、岩肌のような仕上げが全面に施され、空は無しか一つだ け穿たれている。(6)外壁からがラスを後退して設えたバルコンに垂直ルー バーを並べる「バルコのルーバー分割」。垂直ルーバーがバルコンを繰返し分割す るため、壁面には彫りのある矩形パタタが並ぶ。(7)GL から軒まで届く 垂直ルバーを壁体に組み込んだ「垂直ルバー壁」ルーバーの垂直線が上下 層を跨いで執拗に繰り返し、そのパ多は裏側の内部空間にも表出す る。(6)違って内部からルバー間に出入りできない。（8)隣り合う室を 雁行型にずらして並べ、屈折する壁面を構成する「雁行型屈折壁」。 各室の壁面は、間口いっぱいの空を持ちா形枠で縁取られている。

以上の構成手法は、壁面に陰影を伴った明暗の効果をもたらして いる。(1)は軒下の陰影の帯と庇の明るい帯が上下に積層し、(2)はファサー ド全体が鷖りのあるヴォイドを抱え、(3)は屋根裏の陰影が壁の上辺を 明瞭にする。(4)は架構の格子が空の矩形暗部を縁取り、(5)は壁面のテク 劝ヤーが壁全体に繊細な陰影を与え、(6)はルーバーのパ多が壁面に彫りを 与える。(7)は日射を遮蔽/反射する縦ルーバーの連続が、光と鷖が混じり 合う被膜状の壁を形成し、8は屈折壁の入隅に陰の溜まりをつくる。

外壁面に付加する要素は、骨組架構の口型パ㚈を日型に分割する

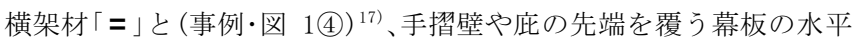
材「口」がみられた(図 1(1)）。こうした水平的な要素は、荷重を分担 しておらず、壁面での位置・幅・後退距離を自由に設定できる。その ため建物の垂直性を静めるなどフアサードのプロポーションを調整している。 他に目をひくのは量塊的な付加要素で、壁面の主入口から前面道路 に向かって大きく伸びる入口キャ价ー「く」と（写真 1 )、量塊的な曲線

\section{図 1. 壁面の構成手法 ( 8 種類)}
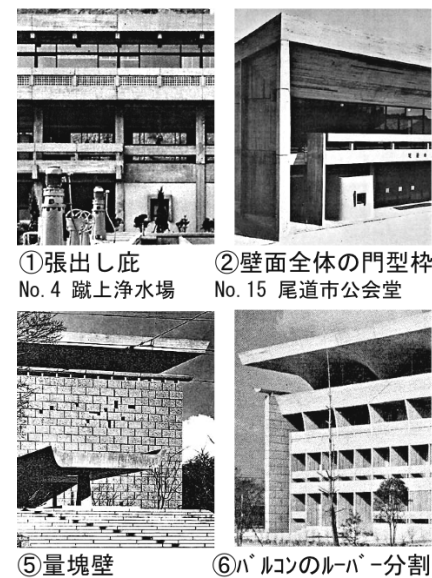

№. 31 智積院会館 No. 31 智積院会館
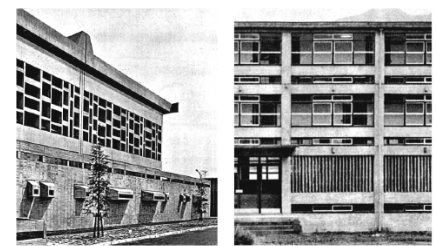

(3)屋根の持上げ №. 44 京大総合体育館

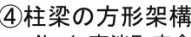

柱梁の方形架棈

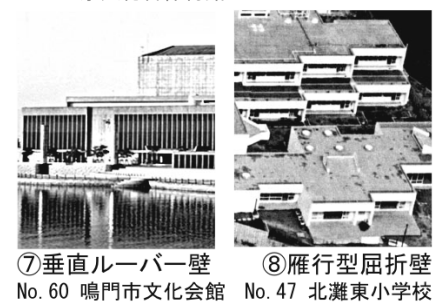
*写真は各手法の典型的事例

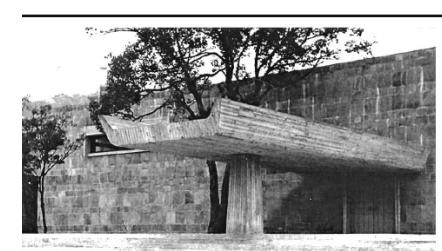

写真 1

No. 20 東山会館 写真 2

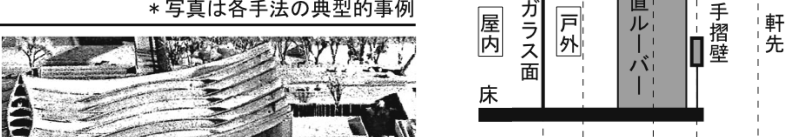

(1) (2) (4) (5)

記号表記 : |バル手軒

表現を伴った要素

(図 2)がみられた。正面から見て両端部が 曲線状に反り上がったキャル゚ーもみられた

$\bullet$ ○)」(図 1(5))

外壁面の断面形状は、36/61 作品が垂直面であった。他に最下層を セッハバッした壁面「マ」、ボリュム付加や傾斜によって上層部が迫出した

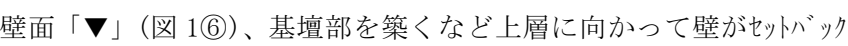
する雛段状の壁面「山」(図 1(3)(7)(8)・写真 2) がみられた。

\section{2-2. 境界を構成する壁面要素の前後関係}

次に内と外の境界を構成する「壁面要素の前後関係」を検討した (図 2 下)。内と外の境界面を構成する壁面要素は、(1)空がラス面「」」 (2)バルコン「バ」(3)垂直ルーバー「ル」(4)手摺壁「手」(5)手摺の外側に張出 した屋根・庇の軒先「軒」の 5 種類みられた。壁面要素の前後関係は、 空がラス|を起点にしてその外側の要素を順番に並記し|バル手軒のよ うに記号表現した。なお軒先が手摺壁と一致する場合は「手」と表記 し、軒先が手摺壁の外に張り出す場合のみ「手軒」と表記した。また 記号一つの| は、がラスと外壁面が一致した平滑な壁を表す。このよう に記号列の長短や組合せから、壁の奥行きや彫りの深さ、壁面の透明 性、屋内と戸外のつながり方を読み取ることができる。

\section{2-3. 壁の造形的性格と四つの時代}

以上の四項目「壁面の構成手法 - 壁の付加要素 · 断面形状 · 壁面 要素の前後関係」を各作品に対して検討した (図 2 )。その結果が表 1 である。表 1 の横軸からは各作品の造形的特徵が、縦軸からは増田 の作風の変遷が読み取れる。使用された構成手法の年代的分布をみ るために、「隣り合う○の間隔が 4 マス以内で○が 6 個以上のまとまり」 を原則としてグレー表示した。するとNo. 20 付近とNo. 40 付近を境目 に、壁の造形を主導する要素が、「庇 $\rightarrow$ 屋根と壁 $\rightarrow$ 壁」と切り替わっ ていることがわかった。このように作品全体は、壁の造形拜つの違い から、「庇」の時代 (No. 1～21)、「屋根と壁」の時代 (No. 20～45)、「壁」 の時代 (No. 40・41〜61) に大分類でき、さらに「庇」の時代は、方形架構 の壁面から「張出し庇」が伸びる前半 (No. 1〜9) と、袖壁と屋根スラブ が壁面全体を枠づける後半 (No. 10～21) に判然と分けることができ

\section{図 2. 分析例（壁の造形的性格）}

分析例 : No. 21 鈴木自動車本館（1963 年 09 月着工）<>は各作品の検討項目

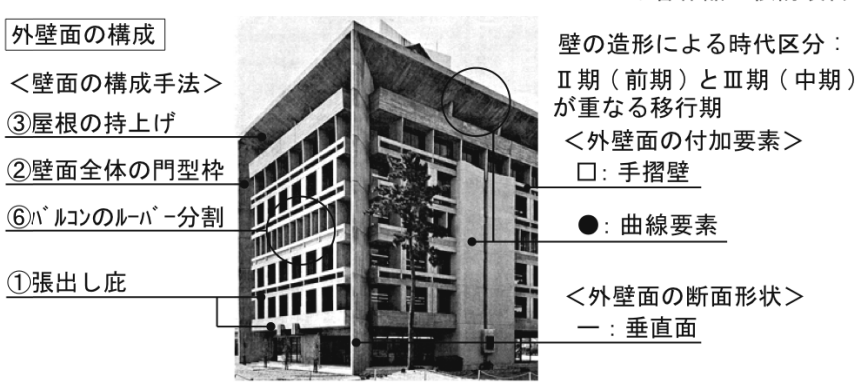

$<$ 壁面要素の前後関係 $>$

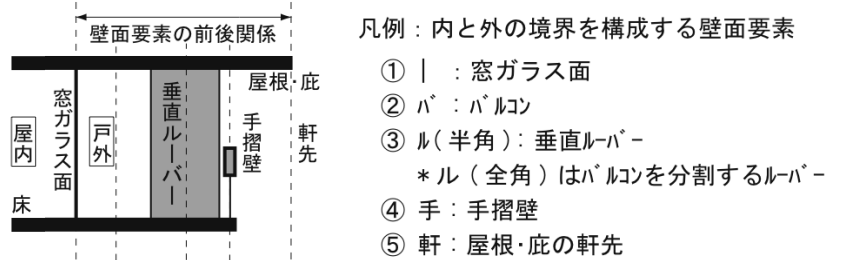

(5) 軒 : 屋根·庇の軒先

*境界面どうしの距離が 2.30ゼチ以内の場合は 一致した面とみなす。

*「手」と「軒」が一致した場合は「手」と表記する。 
る。総合すると増田の建築作品は、壁の造形に焦点を当てた場合 $「 \mathrm{I}$ 期 (初期)」「II 期 (前期)」「IIII 期 (中期) 」「IV 期 (後期)」と呼びうる 四つの時代に区分できる。次章からは各時代の壁の造形的特徴や、 建物の中での壁の捉え方や取り扱いについて述べる。

\section{3. 庇の時代}

I 期 (初期) と II 期 (前期)を通して、壁の造形を主導するモチーフは 「庇」である。「張出し庇」と「門型の枠庇」、張出し庇を省略した 「方形架構の壁面」の三系列の造形がみられた。

\section{3-1. 張出し庇と方形架構の壁}

第 I 期 (初期・1957 1959) のすべての作品は (No. 1～9)、水平材と 垂直材による方形架構が壁面を構成する。梁の延長体である張出し 庇がフアサードをめぐり、各層ごとに水平の帯が走る。庇裏の小梁・梁端 を覆う幕板・手摺壁などのコンクリート部材を、上/下、手前/奥、点/線/面 といった関係で巧妙に組合せ、部材の見え隠れや精緻な奥行が壁面 に与えられている (図 111)【I a 型】。南淡町庁舎や京大工学部校舎 はじめ口ーユス卜の建築では庇は省かれ、「方形架構と横架材による日型 のパ㚈」が壁面全体を覆う（図 14)。横架材の視覚的な水平効果で、 ファサードの層序は曖昧にされ、建物の垂直性が弱められている。壁の 隅々まで均質に構図された中心や焦点のない壁といえる【I b 型】

\section{3-2. 壁面全体の門型枠}

第 II 期（前期·1960～1963）の作品（No. 10～21）は、袖壁と屋根スラブ がフアサード全体を門型に枠づけている(図 1(2) 図 2)。この時期、7/12の 作品が正方形の建築体で、庇やバルコンなど空に付随する要素を壁に吸 収することで、外形の幾何学性が保持されている。門型枠内のヴォ仆 を横断する水平材「口」が立面の構図を引き締め、壁面下部の外バ

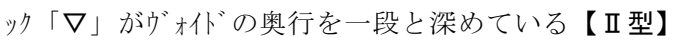

\section{4. 屋根と壁の時代}

第正期 (中期・1963〜 1971) は、屋根とマッシブな壁が壁面の主導モチーフ である(No. 20〜45)。壁から持上げられた屋根は、コンクリートの可塑性を 生かしてシェル構造や PC(プレストレスコンクリート)で伸びやかに造形化され、 建物の上辺を限る (No. 21〜44)。ラーメ構造を包む壁は、支持機能から 解放されていっそう自由に造形化されている。構造に囚われないこ の時期の壁は表情豊かで、壁の在り方が増田の言う「純隔離用壁」一 純粋な隔離のための壁に近づいている ${ }^{18)}$

\section{4-1. 重厚な一枚壁と量塊的表現}

道路側のフアサードに、重厚な一枚壁を初めて据えたのが No. 20 東山 会館(写真 1) である (No. 20〜41)。壁はコーナーで回り込まずに袖壁とし て余分に伸び、「一枚の壁」として明確に分節化されている(図 15)(6) 写真 1)。壁面からは、巨大な入口キャ价一が伸び、壁とキャル゚ーがセットで 厚みのあるフアサードを形成している。またキャピーの肉感的な形態が、 前庭の空間に確かな輪郭之形を与えている。一枚壁の表面は、ハッリ仕 上げや型枠の目地模様が施され、コンクリートの素肌とは趣の異なる岩肌 のような量塊的表現が与えられている(図 15)【III 型】

\section{4-2. バルコンのルーバー分割と彫刻的表現}

No. 14〜45 の比較的長い時期みられるのが、バルコンのルーバー分割に よる彫刻的な壁である。コンクリート壁の懷に深く入りこんだバルコンを、垂 直ルーバーが区画するため、壁面には彫りのある矩形が並ぶ。正方形や 黄金比など幾何学の秩序で構図された矩形群は、ボリュームに穿たれた 「穴」であると同時に、視覚に訴える「パ外でもある【亚b 型】。

No. 21 鈴木自動車本館は、壁が四面とも「バルコンのルバー分割」で、 壁の層が |バル手軒と厚く、最も彫琢された印象を受ける作品である (図 2)。優美な大屋根を浮かせた No. 31 智積院会館は、出入口のある 東西の妻壁が量塊壁、南北の側壁が彫刻壁で、彫刻壁を手前に傾斜 させて壁の量感を一段と強調している(図 15)(6)。こうした二種類 のマッシブな壁の併存は、No. 20、23、27、30、39 の作品でもみられる。

\section{5. 壁の時代}

第 $\mathrm{IV}$ 期（後期・1968～1980）の作品 (No. 40・44～61) は、壁がモチーフ で、「垂直ルーバー壁」と「雁行型屈折壁」の二系列が同時展開する。 面の重なりが少ない簡潔な壁が、中期の重厚な壁に取って代わる。

表 1. 壁の造形的性格

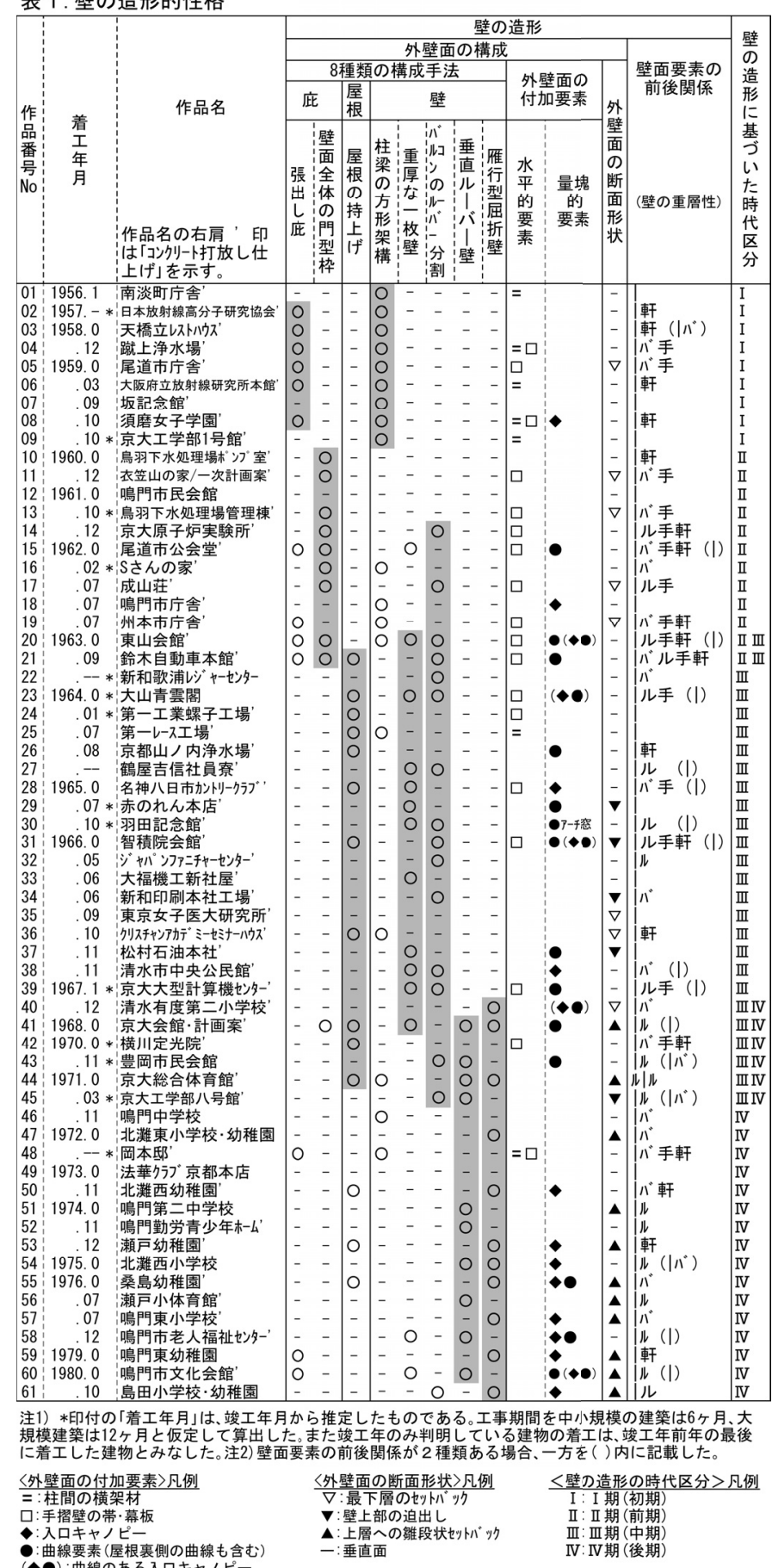




\section{5-1. 垂直ルーバー壁}

ルーバーと壁が一体化した「垂直ルバー壁」の初出は、1968 年・京大 会館である (写真 2)。京大会館は敷地中央に体育館兼オーディ訬アム 吊り屋根の懸垂曲線と側壁がフアサード 全体を門型に枠づける大建築一 を配置し、その周囲を屈折する回廊や中庭、低層施設が囲む。低層部 の壁は、量塊壁を差し挟みつつも基調となるのは垂直ルーバー壁「|ル」 である。等間隔」と「ランダム」の二種類のルーバー配列は、壁に面した空間 に律動感を与え、浅く透けた壁は、内部空間と屋外を浸透させる。

三年後、同じ敷地に建てられた No. 44 京大体育館は、大階段の基壇 部に壁と屋根が載る古典的な三層構成の建物である(図 1(3)。壁は 四面ともランダ配列の垂直ルーバー壁で、壁の屋内側にも外と同じパ㚈 のルーバー壁が四面に取り付けられた。外ルバーと内ルーバーが半透明がラス

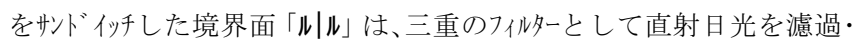
拡散し、スポーツ活動に適した柔らかな光を内部に届ける。

IV 期の後半、鳴門市の文化施設 No. 52・58・60 は、プラザを囲むよう に建ち、等間隔の垂直ルーバー壁「|ル」で外観を統一している(図 17)。 見付 $150 \mathrm{~mm} 、 \mathrm{GL}$ から軒までの高さ三層分のコンクリートルバーは、方立(刉才 ン)のように壁に沿って整然と並ぶ。半ば面的表現といえるルーバーの反 復は、プラザに一定の包囲感をもたらす。と同時に内部にも表出し、内 と外の空間を同時に秩序づけている。中期の彫塑的な壁から転じて、 「開きつつ閉じる」半透明の相をした壁が実現している【I

\section{5-2. 雁行型屈折壁}

No. 40 有度第二小学校以降、増田は多くの学校教育施設を手がけ る。教室や保育室を片廊下形式で並べずに、部屋を雁行型に配列した 建物が提案された。部屋の数だけ屈折する壁面がフアサードを形成して いる。さらに上階の部屋を下階から後退して、屋上庭園 (ルーフララス)を設 けることも多い。壁面を平面・断面の両方向で屈折して隣室との接 触を減らすことで、外に多く囲まれた独立性の高い学習環境が形成 されている(図 18)【IVb 型】。

こうした学校建築も含め後期になると、基壇部が築かれた雛段状 の壁面「ム」をもつ建物が急増している(図 1(3)(7)。これはルーバー壁 や屈折壁といった「面の重なりの少ない壁」によって失われた「マッ涪 な建築表現」を、建物の全体形に補填する一あるいは全体形に転調 させる操作と考えられる。その他、後期特有の壁面要素として、幼稚 園でのト祅状の入口ボリュームがある（写真 3 )。向かい合う一対の壁を

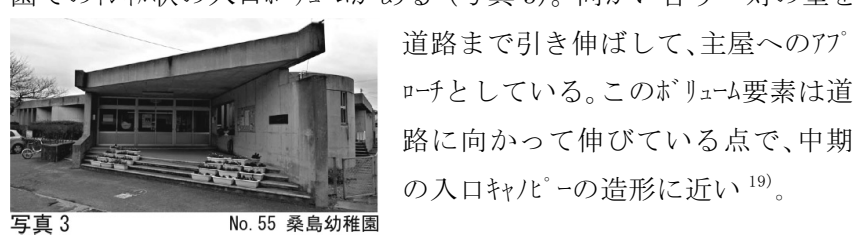

6. 結

以上のように増田の建築作品は、壁の造形に着目すると、 7 つの型 ( I a IVb) と 4 期に渡る変遷という表現形式に則って成立していた。 ファサードの全体的構図を重んじる造形方針と、壁の㻈一に応じてマ゙シブ な表現をアレンジしていく造形展開は、全期に渡って一貫しており、 壁を重視した増田の制作態度のあらわれと考えられる。

前期と中期を橋渡しする東山会館、中期と後期をつなぐ京大会館 は、いずれも五種類の構成手法を同時に用いて、壁を豊かに調子づけ ている。こうした壁の印象が、一見したところ曖昧で大らかなのは、 前の時代に培われた造形と、新たな造形の萌芽をうまく溶け込ませ
ているためである。こうした型にはまらない未 分化な造形の壁は、建物が生成するさまを見る ようで創意に富んでいる。遺作となった鳴門市 文化会館も、すべてがコンクリート打放しで造られた。 建物の外壁一周を展開し一枚の壁に見立てると 形態の異なる 17 種の壁が、区切れよく標本レリー> のように連なっている。ここでの壁の多彩な表 情一特に抽象彫刻のように彫琢された中庭の造 形は、壁を重視した設計活動の締め括りに相応

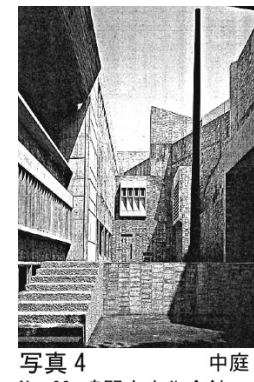
№. 60 鳴門市文化会館 しい相貌といえよう(写真 4)。

\section{参考文献}

1) 京都大学工学部建築系教室 増田研究室記念事業会編 :『増田友也先生退官 記念 著作・作品目録』, 私家版, 1978（目録に、最初期の住宅作品群は除外し たとの記載がある。また増田は京大退官後も設計活動を行ったので、退官後 に計画・竣工した鳴門東幼稚園と島田小学校・幼稚園は掲載されてない。

2）増田友也著作集編集委員会: 『増田友也著作集 (全五巻)』,切ニシ中出版, 1999

3） 1968 年から 72 年にかけて計画・竣工した 5 作品を紹介した、栗田勇編: 『現代建築家全集 14』, 三一書房, 1972 (pp. 51〜79, 192〜198, 209, 212〜213) があるが、その内容は三十年に及ぶ増田の設計活動の一部分といえる。

4)「壁による隔離」を建築の初発的表現として取りあげた増田の論文は多い。 例えば、「隔離一壁」「壁と私と空間とー建築家にとって空間とは何かー」 「日本の空間表現について」(いずれも『増田友也著作集 I 巻』に所収)や 「建築計画概説」(『建築士コース』所収, 産業図書, 1953) 等がある。

5）渡辺豊和：同棲集団と増田友也，『建築評論』，第 8 号, pp. $77 \sim 83$, 建築評論社, 1973 なお文献 5)から 13)は出版年月の古い順に並んでいる。

6) 加藤邦男: 建築学教室の講座 6 . 建築意匠学講座, 『京都大学工学部建築学 教室六十年史』pp. 124 129 京大建築学教室創立六十周年記念事業会 1980

7）田中喬: 京都 東山会館を訪ねて一私記から一保存について思う,『建築術 の実践 : 京都の場合』, pp. 1〜 76, 切ニシヤ出版, 1989

8）長田直之: 京都建築学派, 『建築 MAP 京都』, pp. 78〜 79，TOT0 出版，1998 9）前田忠直：建築以前一増田友也の思索の方法について, 『日本建築学会大 会研究協議会資料集』, 1999.9

10）前田忠直: 増田友也の思惟,『建築と社会』2000 年 9 月号, 第 942 号 vol. 81 , 日本建築協会, 2000.9

11）松本正 : 遠い楚音…未代見師、増田友也へ，『まちなみ』2003 年 2 月 号, Vol. 27/No. 307, pp. 10 13, 大阪府建築士事務所協会, 2003.2

12）前田忠直：京大体育館前庭の白梅に想う, 『京都大学工学広報』, No. 49 , 京都大学大学院工学研究科・工学部, 2008.4

13）前田忠直：増田友也, 『建築論辞典』, pp. 216 217, 彰国社, 2008

14) (1)から (3)の文献のなかでも本稿と関わりの深いものは、増田の建築作品 に対して、壁の造形の多様性を指摘し、特徽的な空間構成の手法として「壁に よる隔離」庇による開放」を挙げた文献 10)13)や、代表的作品の作風が直線 的構成から面的表現に、さらに塊 (マッス)の表現一と移行していることを指摘 した文献 11) である。また文献 5) は、増田の建築家像を描こうとした唯一の 文献で、増田への取材と建築作品（特に京都大学総合体育館および同期の作 品）の考察から、増田の建築家としての特異性を指摘している。

15）増田に関する筆者の拙稿は次のものがある。・徳島県鳴門市に現存する 増田友也の建築作品, 日本建築学会大会学術講演梗概集 (九州), PP. 537 538, 2007.8 ・増田友也の「隔離」概念, 同学術講演梗概集 (中国) , PP. 777〜 $778,2008.9$ ・増田友也の建築と庇の意匠-東山会館までの RC 造建築作品に ついて, 同学術講演梗概集 (東北), PP. 243 244, 2009.8

16）分析対象から除外した作品は、肱川橋欄干、ラッ比”ル、丸善石油芦屋業平 給油所、松村石油名古屋給油所、広島原爆災害調查班遭難記念碑、清水市 総合競技場観覧席、および『著作・作品目録』でも除外された最初期の住宅 群である。京大会館は計画案であるが代表的作品のため分析対象に加えた。 『著作・作品目録』には、1978 年 3 月の増田退官時までに計画された作品が 掲載されている。目録にないが分析した作品は、表 1 No.59 o.61である。

17）（）は具体的事例を示している。これ以後（）内の「事例・」は省略する。

18）「隔離一壁」4）を参照（初出：日本建築学会研究報告 16,1951 年 12 月）

19）トン祅状のボリュームは、表 1 では入口キャル゚ーと同じく•で表記した。

[2010 年 6 月 12 日原稿受理 2010 年 10 月 15 日採用決定］ 